\title{
Morphotectonic analysis, structural evolution/pattern of a contractional ridge: Giouchtas Mt., Central Crete, Greece
}

\author{
Kokinou Eleni ${ }^{1, *}$, Skilodimou Hariklia D ${ }^{2}$, Bathrellos George D ${ }^{2}$, \\ Antonarakou Assimina ${ }^{2}$ and Kamberis Evangelos ${ }^{3}$ \\ ${ }^{1}$ Department of Environmental $\&$ Natural Resources Engineering, Technological Educational Institute of Crete, \\ 3 Romanou Str. Chalepa, Chania, Crete, GR 73133, Greece. \\ ${ }^{2}$ Department of Geology \& Geoenvironment, National \& Kapodistrian University of Athens, University Campus, \\ Zografou, ZC 15784, Athens, Greece. \\ ${ }^{3}$ Formerly, Hellenic Petroleum (Exploration and Exploitation of Hydrocarbons Division), \\ 199 Kifissias Av., 15124 Maroussi, Athens, Greece. \\ *Corresponding author.e-mail: ekokinou@chania.teicrete.gr
}

The Giouchtas Mountain is situated south of Heraklion, Central Crete. It is a N-S trending morphological asymmetric ridge with a steep western slope, whilst its eastern slope is characterized by a smoother relief, composed of Mesozoic limestone and Eocene-lower Oligocene flysch of the Gavrovo-Tripolis zone. The present study focusses on the structural pattern and development of Giouchtas Mountain. Morphotectonic analyses in combination with field mapping and tectonic analysis were performed for this purpose. GIS techniques were used for mapping the spatial distribution of the geological features on the topographic relief of the area. Geomorphic indices, used in the present study, are the mountain front sinuosity index (Smf) and the valley floor/width ratio index (Vf). Based on Smf and Vf values, it is implied that this area can be assigned to a tectonic class I, corresponding to higher tectonic activity. However, spatial variations of the tectonic activity along the segmented fronts point to a general trend of increasing activity towards the north and especially, northeast. The model of this possibly active structural feature corresponds to a compressional mechanism followed by an earliest Mid. Miocene to Holocene late-stage deformation related to extensional faulting.

\section{Introduction}

Crete is situated in the outer-arc region of the Aegean-African subduction system. Recording $\mathrm{N}-\mathrm{S}$ and $\mathrm{E}-\mathrm{W}$ stretching forms a complex mosaic of tilt blocks and associated late Miocene and younger sedimentary basins (Meulenkamp et al. 1988; van Hinsbergen and Meulenkamp 2006; Kokinou and Kamberis 2009; Kokinou et al. 2012). The topography of Crete is therefore characterized by a highly mountainous landscape, suggesting rather young and rapid uplift (Pirazzoli et al. 1982, 1996;
Stiros 1996; Roberts et al. 2013; Gallen et al. 2014). A fast rise of the island is also indicated by Neogene marine deposits of middle Miocene to early late Pliocene age that have been uplifted up to several hundreds of meters above the present sea level (Meulenkamp et al. 1988, 1994). A large number of surface faults underline the essential input of intense tectonic activity on both the surface itself and the landscape evolution (Bonnefont 1977; Angelier 1979).

The Heraklion basin, where the study area is located, comprises a $900 \mathrm{~km}^{2}$ Neogene basin

Keywords. Geomorphic indices; middle Miocene; compression tectonics; Late Neogene-Quaternary; extensional faulting. 
bounded to the east by Dikti Mountain, to the west by Psiloritis Mountains and to the south by Asteroussia Mountains. The Neogene deposits of Heraklion basin overlie the basement rocks of the Upper Nappes (Gavrovo-Tripolis, Pindos, and the heterogeneous Uppermost Unit). The Upper Nappes in the Psiloritis and Dikti Mountains are separated from the HP-LT metamorphic rocks of the lower Nappes (parautochtone Plattenkalk and Phyllite-Quarzite units) by the Cretan detachment (Jolivet et al. 1996; Ring et al. 2001; Ring and Reischmann 2002; van Hinsbergen and Meulenkamp 2006; Zachariasse et al. 2011). This detachment, in many places, is exposed with a sense of shear either to both south and north (Kilias et al. 1994; Fassoulas 1999), or dominantly top to the north (Jolivet et al. 1996). Recent kinematic and structural studies (Chatzaras et al. 2006; Craddock et al. 2009; Tortorici et al. 2010) emphasize the important role of the compression (also supported by the present work) in the exhumation mechanism of the high-pressure rocks exposed on the island of Crete.

The evolution of a landscape is the result of complex interactions involving climate, tectonic and surface progress (Burbank and Anderson 2001). Therefore, the study of the geomorphology assist in understanding the landscape evolution (e.g., Bathrellos et al. 2009a; Migiros et al. 2011; Kamberis et al. 2012) and to estimate the geomorphologic hazard (Skilodimou et al. 2003; Bathrellos et al. 2009b, 2012, 2013; Rozos et al. 2011, 2013; Panagopoulos et al. 2012; PapadopoulouVrynioti et al. 2013). Moreover, in active tectonic regions geomorphic features is an essential tool to recognize active movements, assisting the studies of the tectonic geomorphology (Keller and Pinter 1996; Azor et al. 2002). Several studies have proposed that the investigation of the geomorphic features and geomorphic indices such as the mountain front sinuosity (Smf index) and the valley floor width to valley height ratio (Vf index) provide useful information regarding the influence of tectonics on landscape evolution (e.g., Bull and McFadden 1977; Rockwell et al. 1984; Keller 1986; Keller and Pinter 1996; Burbank and Anderson 2001; Cuong and Zuchiewicz 2001; Theocharis and Fountoulis 2002; Silva et al. 2003; Al-Taj et al. 2007; Tsodoulos et al. 2008; Dehbozorgi et al. 2010).

The present work aims at a better understanding of the complex geological conditions and the structural pattern in the mountainous area of Giouchtas (figure 1a) located in the Archanes municipality in central Crete. Specifically, the present work describes the development of a tectonic structure from the Eocene-early Oligocene up to recent times. For this purpose, a morphotectonic analysis in combination with detailed geological and tectonic survey was conducted. Field measurements of outcropping faults, such as fault strikes, fault dips, and slickenside lineations, comprise the most accurate data on fault geometry and reconstruct the structural development of the study area. A 1:5000 digital terrain model, structural, and stratigraphic data were combined in a GIS database. This database enabled not only the easy visualization of the results but also contributed to spatial analyses and correlations among the various geological features.

\section{The study area}

The dominant morphological feature of the study area is the Giouchtas Mountain (Mt.), which presents an elongated shape (figure 1b). It extends $\mathrm{N}-\mathrm{S}$, roughly $5.3 \mathrm{~km}$ long with a maximum altitude reaching 811 m.a.s.l. This mountain presents steep slopes, often interrupted by narrow valleys and it is surrounded mainly by a hilly area where the maximum elevation is $485.10 \mathrm{~m}$.a.s.l. The western flank of Giouchtas Mt. has slopes greater than $60^{\circ}$, while the eastern one is greater than $50^{\circ}$ (figure 1c). As shown later in the present study, the Giouchtas Mt. comprises an asymmetric thrust fault related anticline affected by a late-stage, early late Miocene to Holocene, intense extensional deformation. The narrow plain of Archanes is located east of the mountain.

Giouchtas Mt. is surrounded by streams. The drainage network, developed mostly to the north and to the east of the mountainous area, acquires the largest extension within the study area (figure 1b, c). The Knossanos River stream drains the northern and eastern flanks of the mountain as well as the plain of Archanes. This stream flows to the north, running through Knossos, and reaches the Aegean Sea. Part of this stream runs through a deep canyon with steep slopes in the northeast piedmont of Giouchtas Mt. creating a narrow Vshaped valley (figure 1b, c, northeast of Giouchtas Mt.). The drainage network presents a rather parallel pattern. The western flank of Giouchtas Mt. is drained by streams, forming the upper part of Giofyros River, which also discharges to the Aegean Sea. The flow of the stream shows a dominant NW-SE and E-W trends.

The study area (figures $1 \mathrm{~b}$ and $2 \mathrm{a}-\mathrm{l}$ ) belongs to the Gavrovo-Tripolis zone. According to Brünn (1956) and Aubouin (1959), the external Hellenides in western Greece (Pindos, Gavrovo-Tripolis, Ionian and pre-Apulian zones), consists of a series of subparallel, north-south trending tectonostratigraphic zones including several east-dipping thrust sheets and west verging folds. The Gavrovo-Tripolis zone represents a stable shallow carbonate dominated 


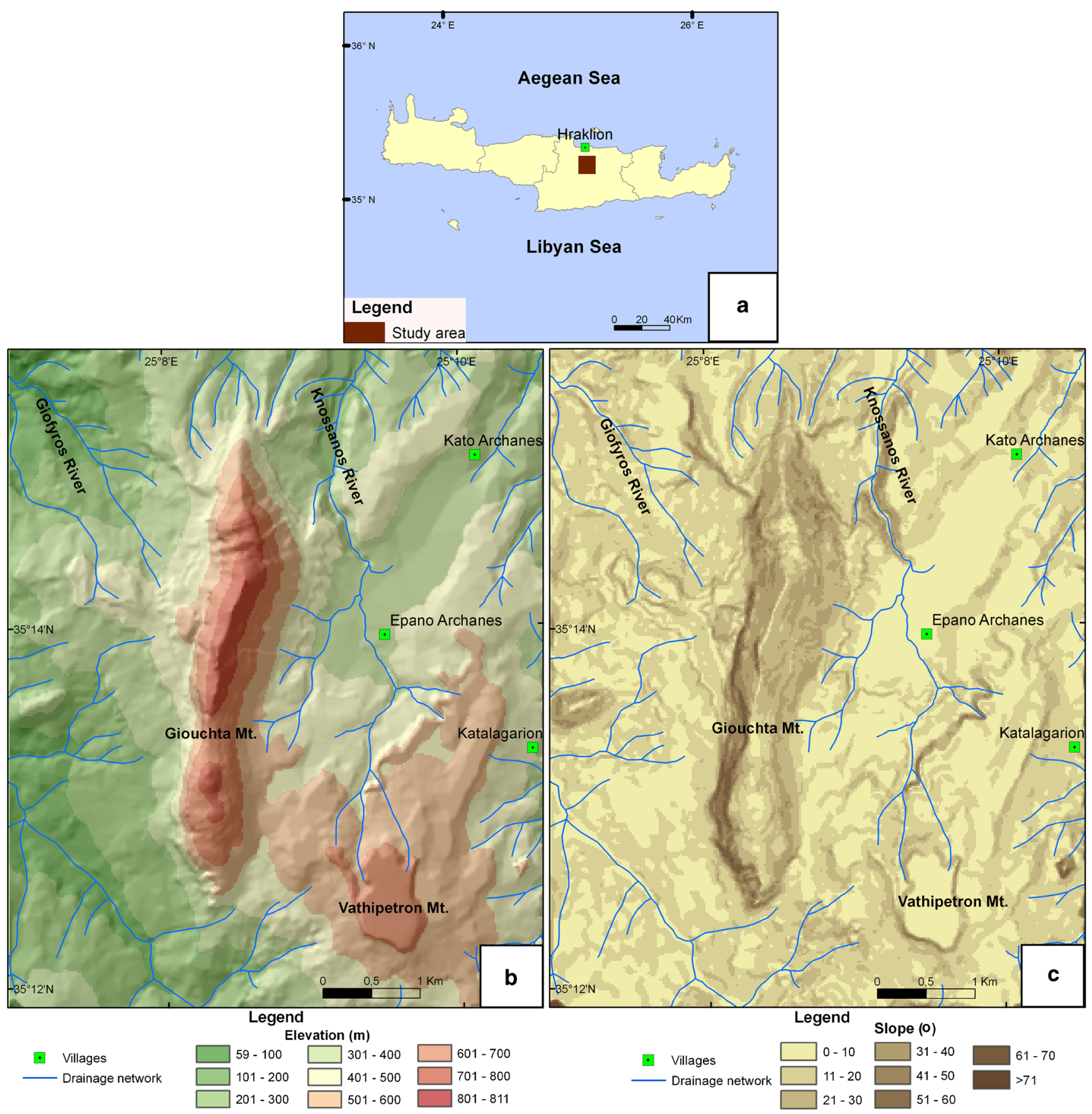

Figure 1. (a) Location of the study area; (b) topographic relief showing the wide area of study with the main structural features; and (c): morphological features of the study area produced from $4 \mathrm{~m}$ digital elevation data.

platform (Dercourt 1964). The Gavrovo-Tripolis sediments include middle Triassic to upper Eocene limestones and Eocene to lower Oligocene flysch (Fleury 1980). The permanent shallow-water sediments of late Jurassic to latest Cretaceous, appear as a distinct unit affected by successive regressive episodes (Bernier and Fleury 1980). According to Alexander et al. (1990), this unit structurally underlies Pindos thrust sheets. The recent work of Chatzaras et al. (2013) and previous research in Crete (Chatzaras et al. 2006; Tortorici et al. 2010) support the presence of a crustal scale oblique ramp (formed above an inherited Mesozoic fault zone) in the external Hellenides thrust belt on Crete.

The carbonate sequences (figures 2a-f, i, 3) exposed in Giouchtas Mt., located in the northern and southern parts of the mountain, comprise Jurassic-lower Cretaceous $(\mathrm{J}-\mathrm{K})$ light grey to grey black, medium bedded to massive, karstic, limestones. Dolomitization decreases from base to top. The central part of Giouchtas Mt. is dominated by upper Cretaceous (Ks.k), grey-black medium-thick bedded, bituminus and dolomitic limestones. Flysch (figures 2h, 3) of upper Eocene-Oligocene age, 

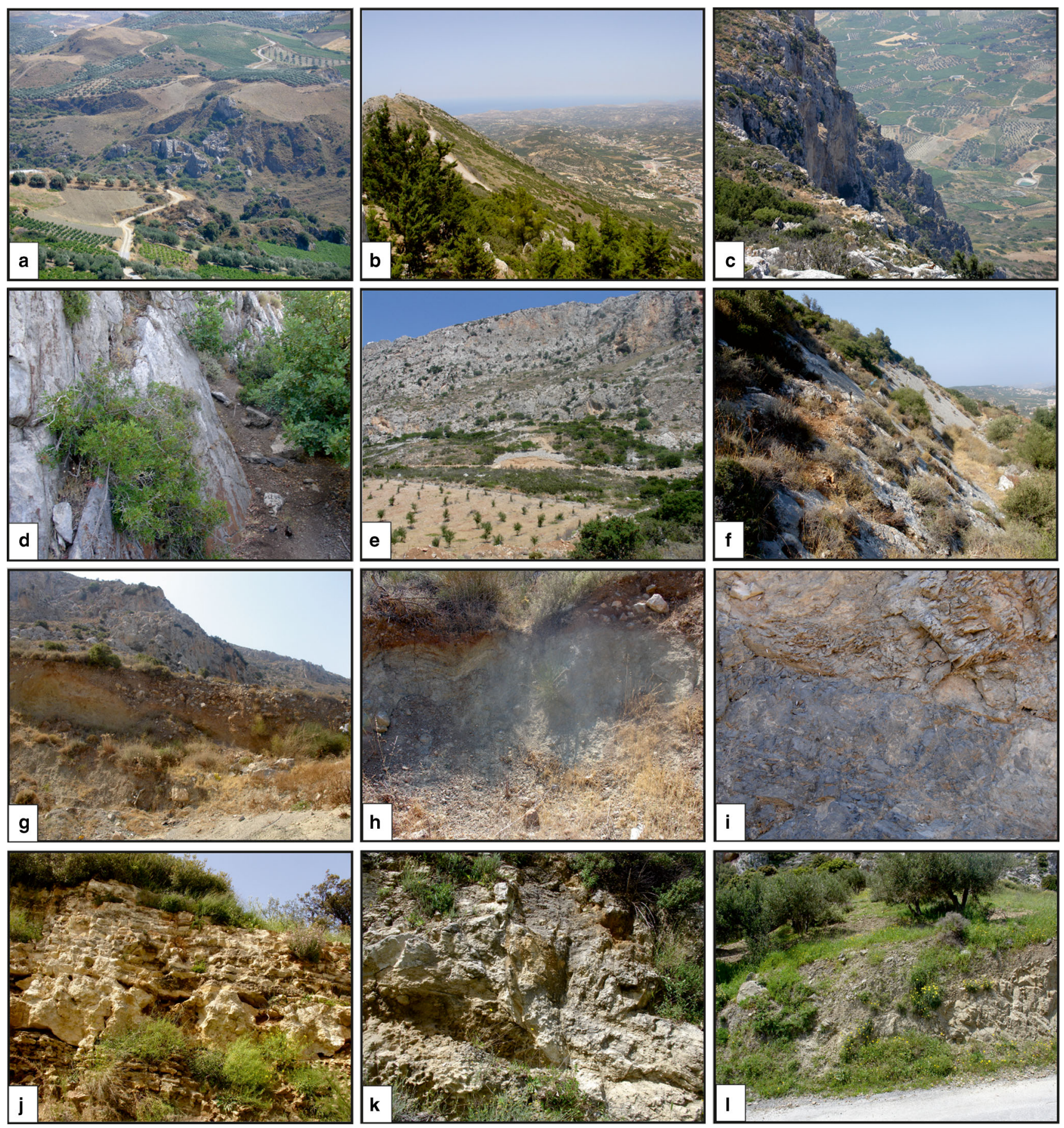

Figure 2. Photos from the study area showing the tectonostratigraphy: (a) view to the west, a carbonate hill surrounded by Miocene sediments is recognised, (b) view to the west, normal fault in the carbonate sequence, (c) location to the west, Jurassic-lower Cretaceous limestones, (d) location to the south, normal fault in Jurassic-lower Cretaceous limestones, (e) location to the west, upper Cretaceous limestones, (f) location to the east, normal fault in upper Cretaceous limestones, (g) location to the west, coarse-grained coherent Quaternary sediments, (h) location to the east, flysch of upper EoceneOligocene, (i) location to the east, contact of Jurassic-lower Cretaceous limestones and upper Cretaceous limestones, (j) location to the west, Miocene formations, (k) and (l) location to the east, Miocene formations.

belonging to the Gavrovo-Tripolis zone, is detected in the north-eastern flank of the mountain, comprising alterations of schists and sandstones with small layers of grey calcareous turbidites.

Miocene sediments (M) around Giouchtas Mt. shown in figures $2 \mathrm{j}, 2 \mathrm{l}$ and 3 , consist of: (a) middle
Miocene fluvial-lacustrine clays (Mm) with local lignite, limestones and sandstones, (b) upper Serravallian marine clays and silty clays with intercalations of sandstones (M.l.st), (c) middle-upper Miocene breccias and brecio-conglomerates (M.pt), (d) Tortonian marine and fluvial conglomerates 


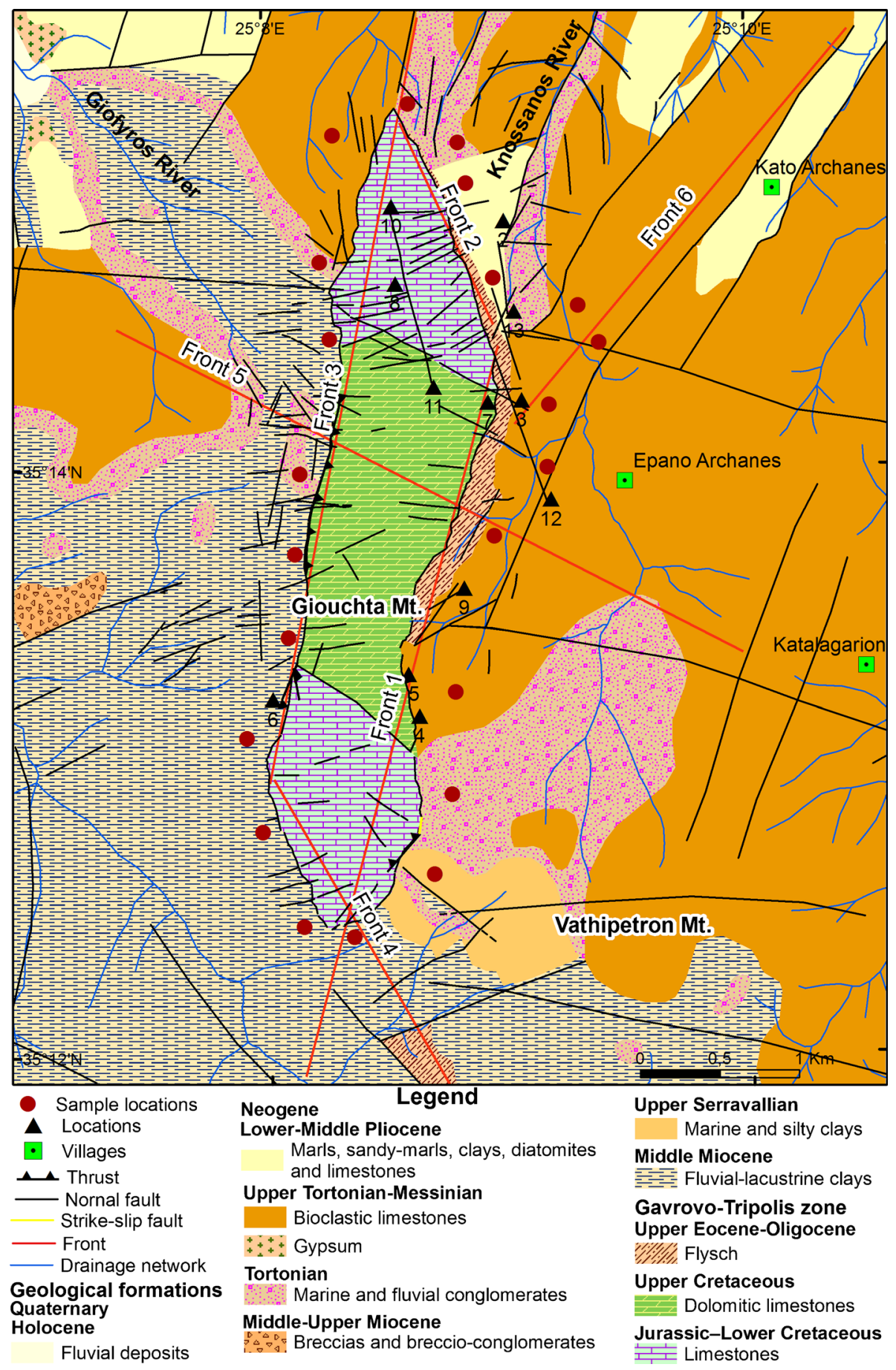

Figure 3. Geological map of the study area, the major mountain fronts, and locations commented in the text. Morphometric data were collected along fronts shown in this figure.

(Mc), sandstones, siltstones, marls, clays, and lignites, (e) upper Miocene bioclastic limestones $(\mathrm{Mk})$ and gypsums (g). The Pliocene sediments (Plm) consist of marls or marly limestones, clays with marls, lamellar marls or diatomites and bioclastic limestones.

Moreover, coarse-grained coherent and loose Quaternary sediments (figure $2 \mathrm{~g}$ ) were observed in several locations of the study area during the fieldwork. Alluvial deposits (al), consisting of loose clay-sandy materials and 'terra rossa', are also present.

\section{Methodology}

\subsection{Geographic Information System (GIS)}

Digitization techniques and GIS were applied for mapping representation of the data. The digital 
elevation model was created by the digitization of the topographic map contours (1:5000 scale maps), while the cell size of the digital elevation model was $4 \mathrm{~m}$. A spatial database was created, and ArcGIS 9.3 software was used to process the collected data. This study was carried out using topographic maps (3 sheets) of a scale of 1:5000, published by the Hellenic Army Geographical Service (H.A.G.S.). A Digital Elevation Model (DEM) was created by digitizing the contours with $4 \mathrm{~m}$ intervals and trigonometric points of the above-mentioned topographic maps. The slope map was derived from the DEM and the slopes were grouped in eight classes: (i) $0-10^{\circ}$, (ii) $11^{\circ}-20^{\circ}$, (iii) $21^{\circ}-30^{\circ}$, (iv) $31^{\circ}-40^{\circ}$, (v) $41^{\circ}-50^{\circ}$, (vi) $51^{\circ}-60^{\circ}$, (vii) $61^{\circ}-70^{\circ}$, (viii) $>70^{\circ}$ (figure 1c). The geological map of the study area was created, based on the existing geological map (IGME, 1:50,000) and field observations.

\subsection{Geomorphic indices}

Geomorphic indices are useful tools in evaluating the tectonic activity (Turowski et al. 2006, 2009; Brocklehurst 2010), relating the sensitivity to rock resistance, climatic change, and tectonic processes with the production of a certain landscape. The most useful indices are the mountain front sinuosity (Smf index, Bull and McFadden 1977) and the valley floor width to valley height ratio (Vf index; Bull 1977, 1978).

Mountain front sinuosity is determined by measuring the length of the mountain front along the foot of the mountain Lmf and the straight line length of the mountain Ls ( $\mathrm{Smf}=\mathrm{Lmf} / \mathrm{Ls})$ (Bull and McFadden 1977). This index reflects the balance between erosion that tends to produce irregular or sinuous fronts and tectonic forces that tend to create a straight mountain front coincident with an active range-bounding fault. Values of Smf approach 1.0 on the most tectonically active fronts, whereas Smf increases if the rate of uplift is reduced and erosional processes begin to form a front that becomes more irregular with time. Smf values lower than 1.4 indicate tectonically active fronts (Rockwell et al. 1984; Keller 1986; Burbank and Anderson 2001), while higher Smf values (>3) are normally associated with inactive fronts in which the initial range-front fault may be more than $1 \mathrm{~km}$ away from the present erosional front (Bull and McFadden 1977).

In this study, the examined fronts were separated in six discrete segments, corresponding to the directions of the major faults present in the study area and they are illustrated in figure 3 by a red line. The fronts (1) and (3) are parallel to the faults trending NNE-SSW at the eastern and western sides of Giouchtas Mt. The fronts (2) and (4) are also parallel to the NWSE trending faults, located at the north-eastern and south-western side of Giouchtas Mt. The front (5) crosses the Giouchtas Mt. corresponding to the general direction of the WNW-ESE trending faults. Finally, the front (6) was examined separately because a group of NE-SW trending faults was present in the northeastern proximity of Giouchtas Mt. Moreover, the selection of the fronts was based on similar geological and morphological criteria such as: (a) intersection with large in scale crosscutting drainage, relative to the front, (b) abrupt changes in lithology (e.g., formation prone to erosion progress, (c) changes in mountain front orientation (Wells et al. 1988). The reported Sm data are the mean values of each front, since five different $\mathrm{Lm}$ values were calculated to measure the mean Sm value (Silva et al. 2003).

The Vf index reflects the difference between Vshaped valleys that are down-cut in response to active uplift (low values of $\mathrm{Vf}$ ) and broad-floored valleys that are eroding laterally into adjacent hill slopes in response to base level stability (high values of Vf) (Bull 1978). The ratio of valley floor width to valley height (Vf) may be expressed as:

$$
\mathrm{Vf}=2 \mathrm{Vfw} /((\text { Eld }- \text { Esc })+(\text { Erd }- \text { Esc })),
$$

where Vfw is the width of valley floor, Eld and Erd are elevations of the left and right valley divides, respectively, and Esc is the elevation of the valley floor (Bull and McFadden 1977). The comparison of the floor width in a valley with its mean height provides an index that indicates whether the stream is actively down-cutting or is primarily eroding laterally into the adjacent hill-slopes. In this way, the index reflects differences between broad-floored canyons (U-shaped) with relatively high values of Vf and V-shaped canyons with relatively lower values (Keller 1986). The Vf index is often measured for the most important valleys along the examined mountain fronts (Bull and McFadden 1977; Azor et al. 2002; Silva et al. 2003). In the present study, Vf index was determined in the valleys of each mountain front. Vf values were calculated in different segments at distances of $20 \mathrm{~m}$ along the stream length with similar geological and morphological characteristics (Verrios et al. 2004). The Vf values of different segments were further statistically processed to specify the mean Vf value and the standard error was also measured.

\subsection{Tectonostratigraphic analysis}

Field work and consequent analysis were carried out applying well tried techniques (e.g., Mercier 1976; Hancock 1985). Data were collected in restricted sites, according to stratigraphic units, to 
facilitate the chronological distinction between the different tectonic phases and firstly correlated with the geological map of Greece (1:50,000), Epano Archanes Sheet and Heraklion Sheet (IGME). When two generations of faulting were present in the same site, they were divided before any numerical analysis. The separation is necessary because the two fault systems are often not mechanically compatible. This procedure was carried out using (a) the simple criterion of relative overprinting between two generations of striations (e.g., Mercier et al. 1989), (b) geometric and morphotectonic elements such as the strike, dip and plane of the faults, the presence of recent screes, facets and fault scarps, (c) the relative dating of the hydrographic network streams, since the low order streams are younger than the high ones (e.g., Kamberis et al. 2012).

The structural analysis of each site has been done as follows: first, the graphical approach of the directional histogram for planes was an important check on the mechanical compatibility between families of faults. The angle of deviation in all cases was $<15^{\circ}$. The former analysis was mainly applied using the right dihedron method and circumstantially the $\mathrm{P}$ and $\mathrm{T}$ axes. Both analyses not only give the three principal axes of the stress field, but also some index, such as the mean standard deviation or angular deviation, which indicates the reliability of the result itself. Tectonic analysis has been done using FP tectonics.

Miocene and Pliocene sediments have been dated by planktonic foraminifera biostratigraphy. 22 samples were collected from the formations near the fronts (figure 3). Biostratigraphic analysis was based on the qualitative analysis of planktonic foraminifera.

\section{Results and analysis}

\subsection{Stratigraphic data}

The fronts (1) and (2) are located in the eastern flank of the Giouchtas Mt. The front (1) consists of Jurassic-lower Cretaceous limestones, upper Cretaceous dolomitic limestones, upper EoceneOligocene flysch (geological map of Greece (1:50,000, Epano Archanes Sheet)) and upper Tortonian-Messinian bioclastic limestones. The age of the last sediments is indicated by the presence of Globorotalia miotumida (figure 4a), Globigerinoides obliquus and Neogloboquadrina acostaensis, belonging to Biozone 11 of Zachariasse et al. (2011). The microfauna assemblage also contains specimens belonging to Bolboforma group, $B$. intermedia and B. clodiusi (figure 4d) supporting an upper Miocene age (Antonarakou and Drinia 2004; Drinia and Antonarakou 2012).

The front (2) consists of Jurassic-lower Cretaceous limestones, upper Eocene-Oligocene flysch as well as Miocene sediments (geological map of Greece (1:50,000, Epano Archanes Sheet)). The Miocene exposure contains fluvial-lacustrine clays of middle Miocene age and Tortonian marine and fluvial conglomerates, which contains planktonic and benthic foraminifera and ostracodes assigned to an inner neritic environment. Pliocene marine sediments are defined by the presence of Globigerinoides ruber and Sphaeroidinellopsis seminulina (figure 4b and c), (Drinia et al. 2008). These sediments were previously reported (geological map of Greece (1:50,000, Epano Archanes Sheet)) as middle Miocene fluvial and lacustrine clays.

The fronts (3) and (4) are located in the western flank of the Giouchtas Mt. The front (3) crosses Jurassic-lower Cretaceous limestones, upper Cretaceous dolomitic limestones, and middle Miocene fluvial-lacustrine clays, as well as upper Miocene bioclastic limestones. The outcropping rocks along the front (4) are: Jurassic-lower Cretaceous limestones, and middle Miocene fluvial-lacustrine clays (geological map of Greece $(1: 50,000$, Epano Archanes Sheet)).

The front (5) is oriented almost transverse to the development axis of Giouchtas Mt. Along this segment, upper Cretaceous dolomitic limestones, upper Eocene--Oligocene flysch and Miocene sediments (middle Miocene fluvial-lacustrine clays, Tortonian marine and fluvial conglomerates, and upper Miocene bioclastic limestones) are observed.

The front (6) is located in the NW edge of the Archanes plain and it is about $3.4 \mathrm{~km}$ long. Upper Miocene bioclastic limestones and Pliocene marls, marly, and bioclastic limestones outcrop along this front.

\subsection{Morphometric analysis}

The location, bounding rocks, trend, length, and the values of the morphometric indices, are presented in table 1. The front (1) has a length of $4.8 \mathrm{~km}$ long and corresponds to a large fault trending $\mathrm{N} 20^{\circ}-25^{\circ} \mathrm{E}$ and the mean value of the Smf index is 1.11 . The Vf values range from 1.21 to 0.052 , while the mean value is $0.43 \pm 0.21$ The front (2) is $1.5 \mathrm{~km}$ long and borders another fault trending $\mathrm{N} 157^{\circ} \mathrm{E}$, the $\mathrm{Sm}$ mean value is 1.09 , while Vf values vary from 0.24 to 0.22 and the mean value is $0.23 \pm 0.015$, lower compared to the $\mathrm{Vf}$ of the front (1).

The fronts (3) and (4) correspond to lengths of 5.5 and $2.7 \mathrm{~km}$, respectively. These are situated near the faults trending $\mathrm{N} 15^{\circ}-20^{\circ} \mathrm{S}$ and $\mathrm{N} 140^{\circ} \mathrm{E}$ 


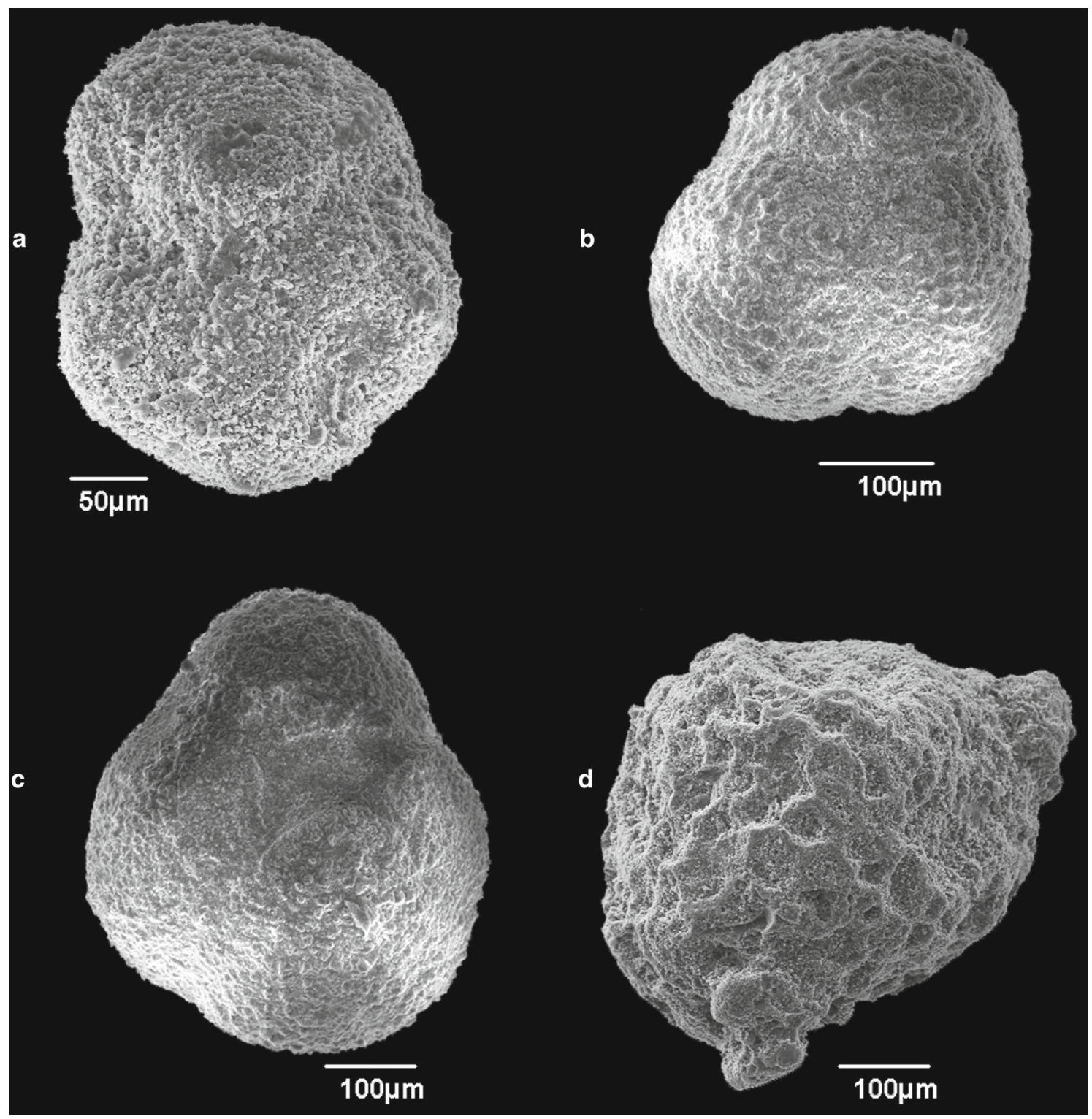

Figure 4. Planktonic foraminifera species from the Neogene sediments east of Giouchtas Mt. (a) Globorotalia miotumida, (b) Globigerinoides ruber, (c) Sphaeroidenellopsis seminulina, and (d) Bolboforma clodiusi.

respectively. The mean value of the $\mathrm{Smf}$ is 1.13 for the front (3) and 1.27 for the front (4). The Vf values range from 1.67 to 0.37 and the mean value is $0.876 \pm 0.14$ for the front (3). The front (4) has values of $\mathrm{Vf}$ varying from 1.21 to 0.32 , while the mean value is $0.7 \pm 0.18$. The mean values of both geomorphic indicators in the west side of Giouchtas Mt. are lower than the eastern ones.

The front (5) is approximately parallel to the border fault zone trending almost $\mathrm{N} \sim 112^{\circ} \mathrm{E}$. The length of this segment is $4.5 \mathrm{~km}$ and the Smf index values decrease from the eastern (2.42) to the western (1.2) flank of Giouchtas Mt. The mean value of Vf is $0.74 \pm 0.17$.

The front (6) is about $3.4 \mathrm{~km}$ long and the value of the Smf is 1.1. The Vf values range from 1.9 to 0.21 , while the mean value is $0.73 \pm 0.15$.
In conclusion, the Sm and Vf values corresponding to the fronts (1) and (2) are lower compared to the values of the fronts (3) and (4), but generally greater activity for the northern part of Giouchtas Mt. is recommended. It should be mentioned that the canyon, located east of the front (2), was probably created due to the tectonic activity related to front (2). The stream, running through this canyon, was probably flowing $\mathrm{N}-\mathrm{E}$ in the past, crossing the plain of Archanes (figure 1c). Due to later faulting in the study area, the stream flowing to the north was rapidly eroded headward along the clastic Miocene deposits. By headward erosion, the stream captured the north-eastward flowing drainage network and led to drainage piracy.

The front (5), striking approximately ESEWNW, presents higher Sm values (2.42) east of 


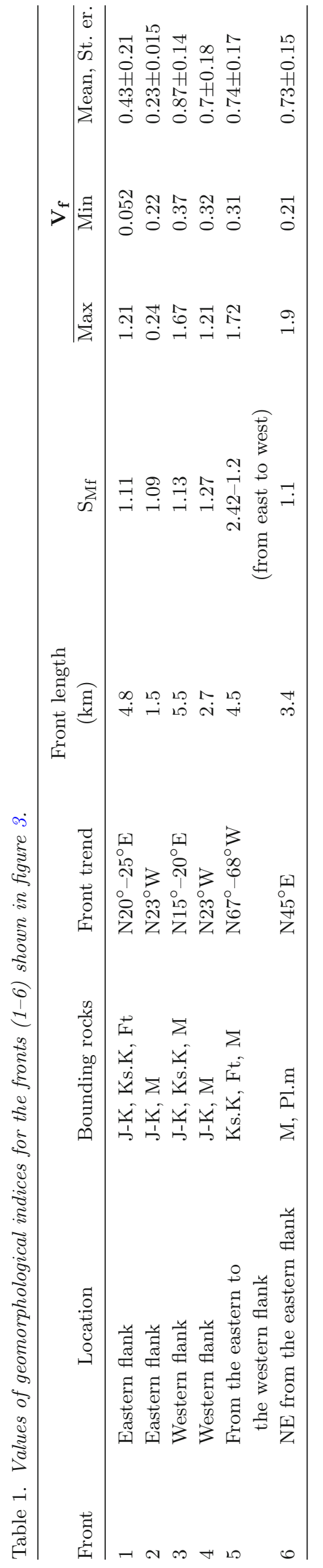

Giouchtas Mt. - Archanes plain - compared to the values (1.2) west of Giouchtas Mt., corresponding to greater activity for the western part of Giouchtas Mt. However, the Vf values for this front are low, possibly related to the recent extensional field affecting the area. Although the exposed Miocene sediments along the front (6) show low resistance to the erosion progresses, the Sm values for this front are low (1.1). Similarly, the Vf value is low suggesting high tectonic activity of the NE trending fault system, located NW of the Archanes plain.

\subsection{Structural data and classification}

Cross-cutting relationships between the members of the different fault systems, morphotectonic features and overprinting criteria were used in order to classify, both compressional and extensional structures (Kokinou et al. 2010) and related stress field patterns.

\subsubsection{Compressional tectonics}

According to Angelier (1979), reverse and strike slip faults on Crete are rare, small and caused by brief compressional events. Moreover, the overall S-directed thrusting that occurred during the Miocene and the earlier contractional events (figure 6), was accompanied by minor back-thrusting. It was associated with both reactivation of preexisting structures and creations of new ones. However, recent studies on the island of Crete (Chatzaras et al. 2006; Tortorici et al. 2010; Chatzaras et al. 2013) propose that the evolution of windows in central Crete was controlled by two main contractional phases of deformation. The first contractional phase is related to NNW-SSE compression resulting in nappe stacking via low-angle thrusting. The second contractional phase was governed by NNE-SSW compression and involved conspicuous thrust-related folding, considerable tectonic imbrication and formation of a middle Miocene basin.

In the study area, the contractional structures, which are bounding the western flank of Giouchtas Mt. (figure 5b), witness contraction-related movements that probably acted in the EoceneOligocene and in the middle Miocene times (figure 6 ). These NW-SE and NE-SW trending movements, respectively, resulted in the formation of an asymmetric anticline, the Giouchtas Mt., which might be related at their latest stage to the ENEWNW contraction tectonics firstly inferred by Benda et al. (1974) and Meulenkamp (1979) for the eastern Mediterranean and Crete. Moreover, a compressional structure recorded in the Jurassic- 

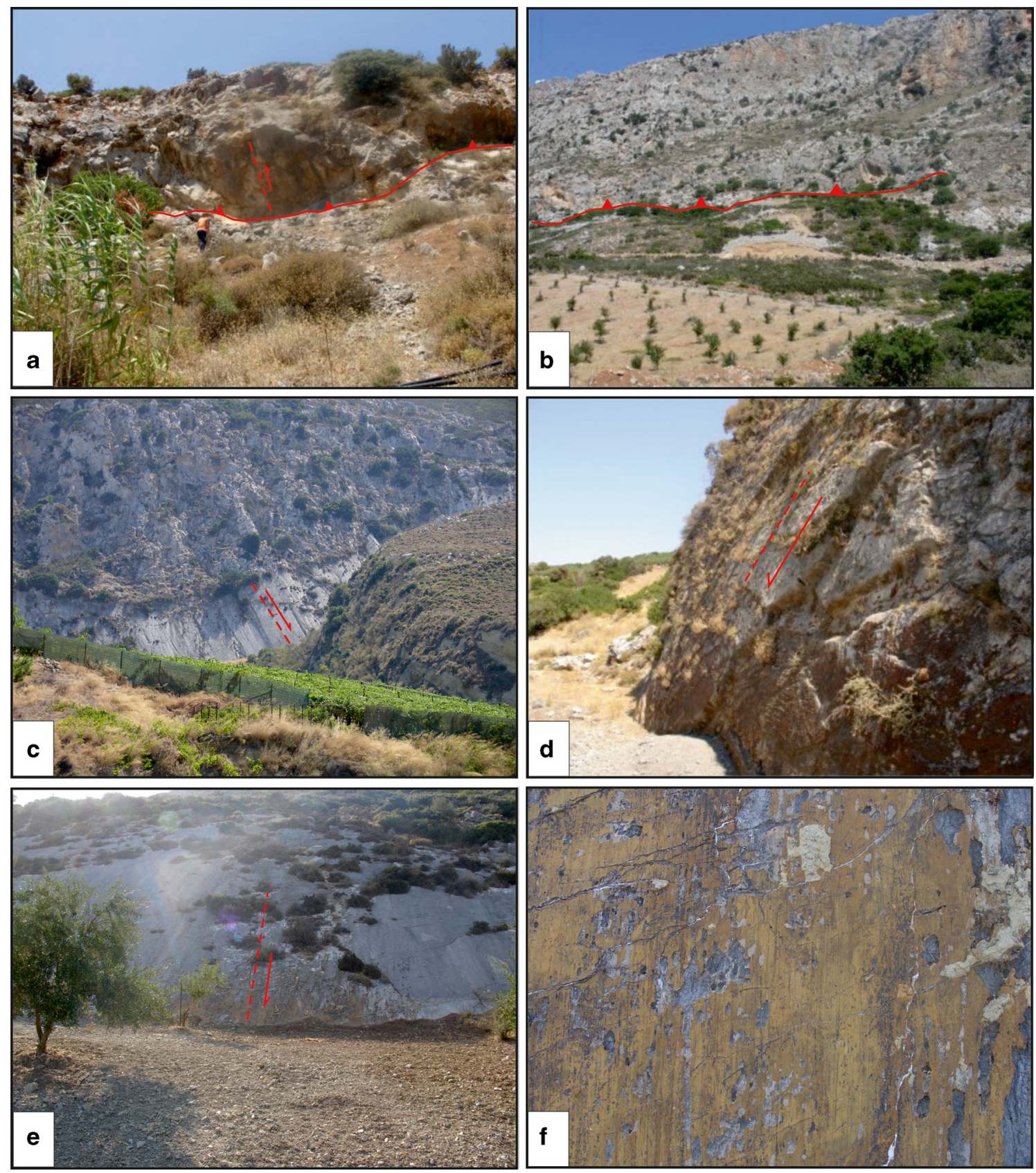

Figure 5. Reverse (a, b) and normal $(\mathbf{c}, \mathbf{d}, \mathbf{e}, \mathbf{f})$ faults in the study area. Direction of slip is indicated by the red arrow.

late Cretaceous rocks presents the NE-SW trending general strike of the Alpine deformation (southeastern flank of Giouchtas Mt., figures 3, 5a, 6). Finally the presence of possible strike-slip fault next to the back-thrust (figures 5a, 6) may be a significant structural element of the exhumation related mechanism (Chatzaras et al. 2006) for the Giouchta Mt.

\subsubsection{Extensional tectonics}

Normal fault systems are indicated in Giouchtas Mt., i.e., late Serravallian, latest Serravallian (?) to early Tortonian, early to middle Tortonian, late Tortonian, early Pleistocene and finally middle Pleistocene to recent times, depicting the abovementioned tectonic episodes. The results of the fault plain analysis, the fault strike classification and the correlation to similar studies in the central and eastern Crete, are shown in detail in figure 6.

First fault system (E-W). The first group includes, roughly $\mathrm{E}-\mathrm{W}$ trending, in the order $\mathrm{km}-$ scale faults (figure 3) active until late Serravallian times. Angelier (1979) supported that large normal block faulting probably occurred in Serravallian 


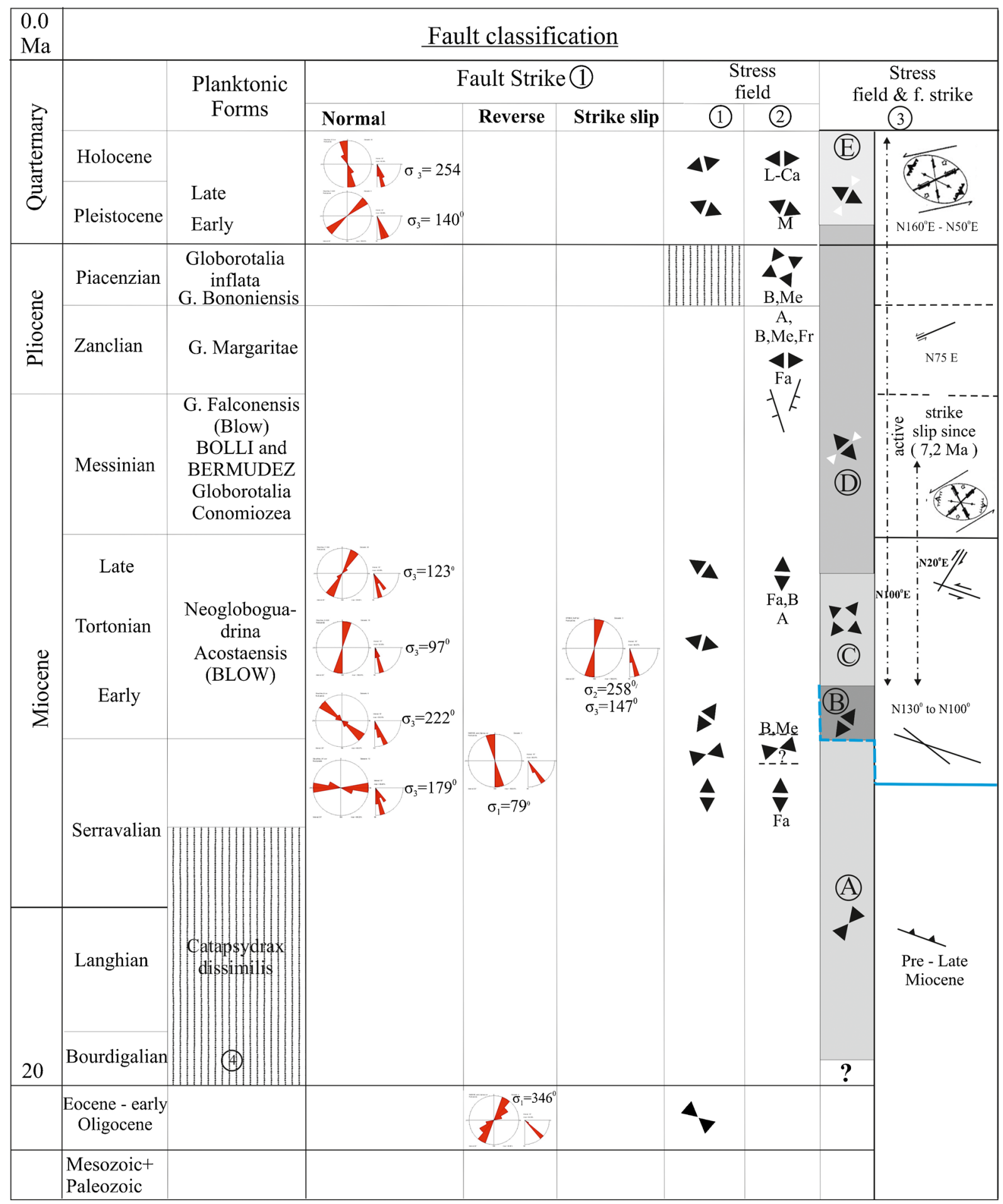

Figure 6. (a) Schmidt projections of the dominant faults (extensional, compressional and possible strike slip) and slip vectors on them resulting from the fault plane analysis. Sites of measurements are indicated by Gni (normal), Gri (reverse), Gsti (strike-slip), where $\mathrm{i}=1,2, \ldots$ (b) Fault classification in Giouchtas Mt. (1) and comparison to other studies (2) Central Crete: B = Benda et al. (1974); A = Angelier (1979); Me = Meulenkamp (1979); M = Mercier (1981); Mercier et al. (1989); L-Ca = Lyon-Caen et al. (1988); Fr = Frydas (1998); Fa = Fassoulas (2001); (3) Central/Eastern Crete (ten Veen and Postma 1999).

times. Fault surfaces and kinematical indicators of these faults are not well preserved. However, overprinting relationships (based on fault intersections and stratigraphic boundaries) indicate that it might correspond to the group A (figure 6, column 3) determined in the central and the eastern parts of Crete by Benda et al. (1974), Meulenkamp (1979), Frydas (1998), ten Veen and Postma (1999). Few, E-W general trending, members of this group (figures 3,6) seem to be intersected 
by the Giouchtas Mt. Ridge, supporting that they probably acted in earlier times than the contraction-related movements referred by Benda et al. (1974) and the present study.

Second fault system (N120E-N140E). The second group, belonging to the N120E (to N140E) trending, presents high angle surfaces and normal dip slip component. These faults mainly cut the older, pre-neogene and neogene rocks (Location 1 in figures 3,5c). However, tectonic movements on some fault surfaces may indicate that the corresponding episode started earlier, probably at the latest Serravallian times. All these faults are intersected by N20-28E fault (figure 3, Locations 2, 3, 4) observed in abundance (ten Veen and Postma 1999) in central Crete at the eastern side of Ida Mountains. Tectonic status at the location (1) corresponds to $\mathrm{N} 222^{\circ}$ extension which is similar to the earliest Tortonian episode referred by ten Veen and Postma (1999).

Third and fourth fault systems (N00EN020E and N030-40E). The third and the fourth groups belong to the N00E-N020E and to the N030-40E trending faults, respectively. Both groups show generally high angle surfaces $\left(70^{\circ}-80^{\circ}\right)$, except a small number of faults belonging to fourth group that show medium $\left(50^{\circ}-60^{\circ}\right)$ and normal dip slip component. The differentiation between the two groups is mainly based on the stress field $\left(\sigma_{3}=97^{\circ}\right.$ to $\left.123^{\circ}\right)$. These members deformed the older generations of faults (Locations 1, 5, 6 in figures 3 and $5 \mathrm{~d}$ ) and are mainly related to the middle and the late Tortonian tectonic activity. At this point, we have to refer that strike slip motion (figure 6) has also been indicated in two members of the third group. Similar strike slip motion has been reported by ten Veen and Postma (1999) in the same period. These authors referred that the late Tortonian to early Messinian episode is marked by important tectonics, related to the beginning of N075E-orientated oblique slip. Faults, belonging to the N020E trending system, bound the Giouchtas Mt. (Locations 5, 6 in figure 3) as it is also inferred by Fassoulas (2001). At location (4), N10-20E fault post-dates the older N110-112E trending structure, while it is cut by a N160-165E fault (Location 7 in figure 3). It is also noteworthy, that ten Veen and Postma (1999) referred the strong vertical fault movement along N020E, including the Sitia Fault Zone, Ierapetra Fault Zone (Gaki-Papanastassiou et al. 2009; Alves and Lourenço 2010) and the W Dikti Fault Zone.

The reactivation of normal faulting along the older, roughly E-W trending, extensional structures, during early Messinian, characterized by a roughly dip slip component (close to the locations 1 and 8 in figure 3 ) is also supported by this work.

Fifth fault system (N040E-N060E). The fifth group of extensional structures includes the N040E to N060E trending faults showing high angle surfaces and normal dip slip component (Locations 3, 9 in figure 3). These are moderatescale NE-SW striking faults (figure 6, column 3) associated with the Pleistocene to recent times tectonic activity. At the location (9) in figure 3, N050E trending faults formed a small graben. However, the dextral lateral motion, referred by ten Veen and Postma (1999) for similar structures in the central and the eastern Crete, is not observed in this area.

Sixth fault system (N160E-N180E). The sixth group includes the youngest members, belonging to the N160E-N180E trending faults (Locations 3, 4, 5, 10, 11, 12 in figure 3 and in figure $5 \mathrm{e}, \mathrm{f})$. They present high angle surfaces and normal dip slip component, too. Especially, at locations (3) and (13), part of the flysch is trapped between two similar faults with significant vertical throw. Faults belonging to the N160E group intersect all the above-mentioned faults and are probably associated to the radial extension dominating in the southern Aegean area (Angelier et al. 1982). This group is also indicated in adjacent areas covered by Holocene sediments. Armijo et al. (1982) and LyonCaen et al. (1988) stated for the first time, that at present, Peloponnesus and Crete are dominated by approximately E-W extension and dip-slip movements along approximately $\mathrm{N}-\mathrm{S}$ orientated faults. Our field data are in agreement with this. However, the last two groups could be equivalent to the episode ' $E$ ' shown in figure 6.

\section{Discussion}

The Cretan syn-orogenic detachment (Jolivet et al. 1996, 2003, 2013), running from the northern Peloponnese to the east of Crete is indicated between the Phyllite-Quartzite nappe and the overlying Gavrovo-Tripolitza nappe. This shallow-dipping extensional detachment was formed subparallel to a subjacent subduction thrust, in the early Miocene (Kilias et al. 1994; Ring and Reischmann 2002). Moreover, it is associated with the formation of a supra-detachment basin of middle Miocene age (van Hinsbergen and Meulenkamp 2006; Zachariasse et al. 2011). Reactivation as a postorogenic detachment has been reported in the Peloponnese on the eastern margin of the Parnon Range (Jolivet et al. 2013). From the Pliocene 
onwards, steep normal faults, trending $\mathrm{N}-\mathrm{S}$ or NE-SW are in abundance in Crete.

Giouchtas Mt. is possibly a contractional feature (asymmetric anticline) in this supra-detachment basin of middle Miocene age, related to the abovementioned stress fields (figure 6). The compressional stress fields, inferred by the present study, are also supported by other authors and might be associated to the crustal thickening that continued on Crete probably until some weakly-defined time in the late-middle Miocene (e.g., Mercier et al. 1989; Jolivet et al. 1994, 1996; ten Veen and Postma 1999; Jolivet and Brun 2010). Additionally, it is noted that our data are also in agreement with kinematics and structural data from the tectonic windows of eastern Crete and Dodecanese islands (Kokkalas and Doutsos 2004). Following the contraction tectonics, successive, distinct, extensional episodes took place creating six fault generations considered herein. Based on Smf and Vf values, the study area is assigned to a tectonic class I, corresponding to the higher tectonic activity. This is also supported by previous studies (Delibasis et al. 1999; Kokinou et al. 2008) concerning the distribution of the microseismicity and seismotectonic structure for the broader area of Heraklion basin. The activity of the fronts (1) and (2) seem to be in agreement with the recent structural pattern corresponding to two generations of faults striking NE-SW and almost N-S, associated with the Pleistocene to recent times tectonic activity. Furthermore, the activity corresponding to fronts (3) and (4) is also high, suggesting that the northern part of Giouchtas Mt. is sinking to the north. This activity is related to the deposition of Quaternary to recent clastic sequences.
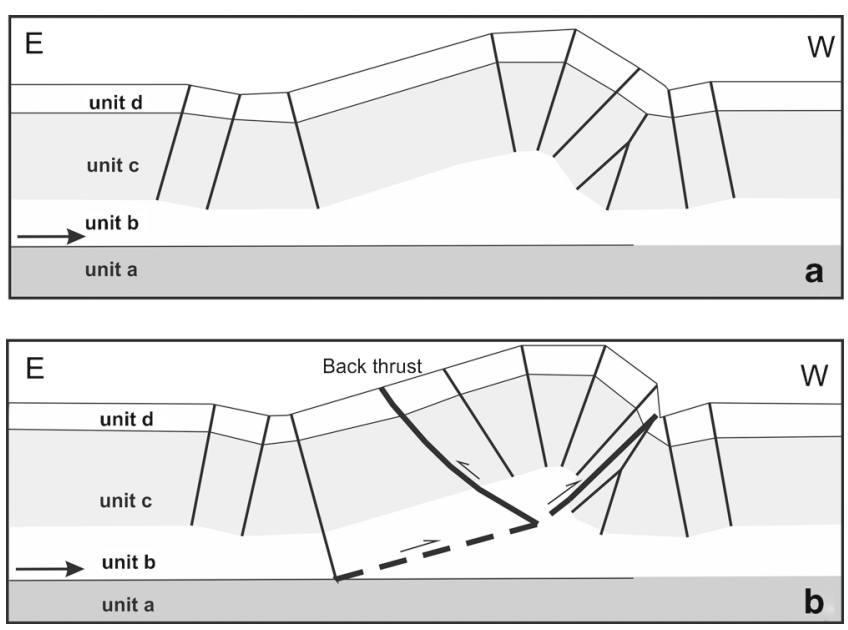

Figure 7. The most likely development stages of the Giouchtas Mt. (Mitra 2002): (a) growth of fold by rotation of limb segments possibly initiated in Eocene-early Oligocene and (b) propagation of the fault through competent units a, b, c, d (explanation in the text).
Taking into account the morphotectonic and structural analysis, the model of figure 7 (Mitra 2002) is proposed to explain the structural development of the present asymmetric anticline. An asymmetric detachment fold should be developed in a following rock package, characterized by high competency contrast between detachment and cover units. It consists of a thin incompetent detachment unit (a), possibly the basement of the study area, and thick competent units (b) and (c), prone to flexural, possibly differential slips. Finally, an uppermost thin moderately competent unit (d) seems to be prone to some internal strain. Fold growth involves limb rotations and hinge migrations in an early stage, possibly initiated in Eocene-early Oligocene, followed by fault propagation through the competent folded unit. This fault (figure 5b) temporarily ends within the deformation zone in the upper competent units of the forelimb and within the upper levels of the detachment unit. It eventually breaks through the whole forelimb and connects with basal detachment. Backlimb is also deformed by a back-thrust fault (figure 5a). Later extensional tectonics (figure $5 \mathrm{c}, \mathrm{d}, \mathrm{e})$ further deformed the present, possibly active tectonic feature resembling the late Neogene contractional structures and related tectonic models presented by Chatzaras et al. $(2006,2013)$ and Tortorici et al. (2010).

\section{Conclusions}

In this work, a model is proposed concerning the structural development of a contractional structure (i.e., Giouchtas Mt.) in a supra-detachment basin. This model is derived by morphotectonic, stratigraphic, and structural analysis.

More specifically, the mountain fronts of the eastern and western flanks of Giouchtas Mt. generally correspond to low Sm and Vf values, indicating active uplift of the study area, also supported by the structural results.

Giouchtas Mt. is an example of a pre-existing contraction-related structure that was strongly deformed in later stages by normal faulting, generated during extensional episodes from latest Serravallian-earliest Tortonian to subrecent times. These episodes indicate stress fields that influenced the area, with $\mathrm{N}-\mathrm{S}$ trending direction since the latest Serravallian times at least, via $\mathrm{NE}-\mathrm{SW}$ in early Tortonian, to WNW-ESE during early to middle Tortonian. The stress field changed to NW$\mathrm{SE}$ in late Tortonian to early Pleistocene times and finally to ENE-WSW in middle Pleistocene to subrecent time-period. Moreover, the reactivation of normal faulting along the older, roughly $\mathrm{E}-\mathrm{W}$ trending, extensional structures, during early 
Messinian, is characterized by a dip slip component of movement. Finally, strain direction changes to ENE-WSW during middle Pleistocene to Holocene times, resulting in the deposition of the recent Quaternary to Holocene sequences.

\section{Acknowledgements}

The authors thank the editor and the anonymous reviewers for their constructive comments.

\section{References}

Alexander J, Nichols E G and Leigh S 1990 The origins of marine conglomerate in the Indus foreland basin, Greece; Sedim. Geol. 66 243-254.

Al-Taj M, Shakour F and Atallah M 2007 Morphotectonic indices of the Dead Sea transform, Jordan; Geogr. Fis. Dinam. Quat. 30 5-11.

Alves T M and Lourenço S D N 2010 Geomorphologic features related to gravitational collapse: Submarine landsliding to lateral spreading on a late Miocene-Quaternary slope (SE Crete, eastern Mediterranean); Geomorphology 123 13-33.

Angelier J 1979 Néotectonique de L'arc Egaen; Ann. Soc. Geol. Nord., Spec. Publ. 3.

Angelier J, Lyberis N, Le Pichon X, Barrier E and Huchon P H 1982 The tectonic development of the Hellenic arc and the sea of Crete: A synthesis; Tectonophys. 86 159-196.

Antonarakou A and Drinia H 2004 The occurrence of Bolboforma, in the Upper Miocene Metochia section, Gavdos island, south of Crete (Greece); Newsl. Stratigr. 40(1/2) 111-122.

Armijo R, Lyon-Caen H and Papanastassiou D 1982 East-west extension and Holocene normal fault - scarps in the Hellenic arc; Geology 20 491-494.

Aubouin J 1959 Contribution a l'étude géologique de la Grèce septentrionale: le confins de l'Epire et de la Thessalie; Ann. Geol. Pays. Hellen. 10 1-484.

Azor A, Keller E A and Yeats R S 2002 Geomorphic indicators of active fold growth: South Mountain-Oak Ridge anticline, Ventura basin, southern California; Bull. Geol. Soc. Am. 114 745-753.

Bathrellos G D, Antoniou V E and Skilodimou H D 2009a Morphotectonic characteristics of Lefkas Island during the Quaternary (Ionian Sea, Greece); Geol. Balc. 38 (1-3) 23-33.

Bathrellos G D, Kalivas D P and Skilodimou H D 2009b GISbased landslide susceptibility mapping models applied to natural and urban planning in Trikala, Central Greece; Estud Geol-Madrid 65(1) 49-65.

Bathrellos G D, Gaki-Papanastassiou K, Skilodimou H D, Papanastassiou D and Chousianitis K G 2012 Potential suitability for urban planning and industry development using natural hazard maps and geologicalgeomorphological parameters; Environ. Earth Sci. 66(2) $537-548$.

Bathrellos G D, Gaki-Papanastassiou K, Skilodimou H D, Skianis G A and Chousianitis K G 2013 Assessment of rural community and agricultural development using geomorphological-geological factors and GIS in the Trikala prefecture (central Greece); Stoch. Env. Res. Risk. A. 27(2) 573-588.
Benda L, Meulenkamp J E and Zachariasse W J 1974 Biostratigraphic correlations in the eastern Mediterranean Neogene. 1. Correlation between planktonic foraminiferal, uvigerinid, sporomorphal and mammal zonations of the Cretan and Italian Neogene; Newsl. Stratigr. 3 205-217.

Bernier P and Fleury J 1980 La plateforme carbonate de Gavrovo-Tripolitza (Grece): Evolution des conditions de sedimentation au cours du Mesozoique; Geol. Medit. 7(3) $247-259$.

Bonnefont J C 1977 La néotectonique et sa traduction dans le paysage géomorphologique de l'Ile de Crète (Grèce); Rev. Geogr. Phys. Geol. 14 93-108.

Brocklehurst S H 2010 Tectonics and geomorphology; Progr. Phys. Geogr. 34(3) 375-383.

Brünn J H 1956 Contribution a l'étude géologique du Pinde et d' une partie de la Macédoine occidentale; Ann. Geol. Pays. Hellen. 13 1-446.

Bull W 1977 Tectonic geomorphology of the Mojave Desert (USGS Contact Rep. 14-08-001-G-394, Office of Earthquakes, Volcanoes and Engineering, Menlo Park, Calif), $188 \mathrm{p}$.

Bull W 1978 Geomorphic tectonic activity classes of the south front of the San Gabriel Mountains (USGS Contact Rep 14-08-001-G-394, Office of Earthquakes, Volcanoes and Engineering, Menlo Park, Calif), 59p.

Bull W and McFadden L 1977 Tectonic geomorphology north and south of the Garlock Fault, California; In: Geomorphology in arid regions (ed.) Doehring D O (Publications in Geomorphology, State University of New York at Bingamton), pp. 115-138.

Burbank D W and Anderson R S 2001 Tectonic geomorphology (Blackwell Science, Inc. USA).

Chatzaras V, Xypolias P and Doutsos T 2006 Exhumation of high pressure rocks under continuous compression: A working hypothesis for the southern Hellenides (central Crete, Greece); Geol. Mag. 143(6) 859-876.

Chatzaras V, Xypolias P, Kokkalas S and Koukouvelas I 2013 Tectonic evolution of a crustal-scale oblique ramp, Hellenides thrust belt, Greece; J. Struct. Geol. 57 16-37.

Craddock J P, Klein T, Kowalczyk G and Zulauf G 2009 Calcite twinning strains in Alpine orogen flysch: Implications for thrust-nappe mechanics and the geodynamics of Crete; Lithosphere 1(3) 174-191.

Delibasis N, Ziazia M, Voulgaris N, Papadopoulos T, Stavrakakis G, Papanastassiou D and Drakatos G 1999 Microseimic activity and seismotectonics of Heraklion area (Central Crete Island, Greece); Tectonophys. 308 (1-2) 237-248.

Cuong N Q and Zuchiewicz W A 2001 Morphotectonic properties of the Lo River Fault near Tam Dao in North Vietnam; Nat. Hazards Earth. Syst. 1 15-22.

Dehbozorgi M, Pourkermani M, Arian A, Matkan A A, Motamedi H and Hosseiniasl A 2010 Quantitative analysis of relative tectonic activity in the Sarvestan area, central Zagros, Iran; Geomorphology 121(3-4) 329-341.

Dercourt J 1964 Contribution a l'étude géologique d'un secteur du Péloponnèse occidental; Ann. Geol. Pays. Hellen. 15 1-418.

Drinia H and Antonarakou A 2012 Palaeoceanography of the Miocene (Tortonian) deposits of the Pre-Apulian zone, western Greece, as recorded by foraminifer and stable isotope records; Int. J. Earth. Sci. 101 521-534.

Drinia H, Antonarakou A and Kontakiotis G 2008 On the occurrence of early Pliocene marine deposits in the Ierapetra Basin, Eastern Crete, Greece; Bull. Geosci. 83(1) 63-78.

Fassoulas C 1999 The structural evolution of central Crete: Insight into the tectonic evolution of the South Aegean (Greece); J. Geodyn. 27 23-43. 
Fassoulas C 2001 The tectonic development of a Neogene basin at the leading edge of the active European margin: The Heraklion basin, Crete, Greece; J. Geodyn. 31 49-70.

Fleury J 1980 Les zones de Gavrovo - Tripolitsa et du Pinde - Olonos (Grèce continentale et Pèloponnése du Nord). Évolution d'une plateforme et d'un bassin dans leur carde alpin; Ann. Soc. Geol. Nord. 4 1-651.

Frydas D 1998 Plankton-Stratigraphie des Pliozans und unteren Pleistozans des SW-Peloponnes, Griechenland; Newsl. Stratigr. 23 91-108.

Gaki-Papanastassiou K, Karymbalis E, Papanastassiou D and Maroukian H 2009 Quaternary marine terraces as indicators of neotectonic activity of the Ierapetra normal fault SE Crete (Greece); Geomorphology 104 38-46.

Gallen S F, Wegmann K W, Bohnenstiehl D R, Pazzaglia F J, Brandon M T and Fassoulas C 2014 Active simultaneous uplift and margin-normal extension in aforearc high, Crete, Greece; Earth Planet. Sci. Lett. 398 11-24.

IGME Geological map of Greece (1:50,000), Epano Archanes sheet.

IGME Geological map of Greece (1:50,000), Heraklion sheet.

Hancock P L 1985 Brittle microtectonics: Principles and practice; J. Struct. Geol. 7(3/4) 437-457.

Jolivet L and Brun J-P 2010 Cenozoic geodynamic evolution of the Aegean; Int. J. Earth. Sci. 99 109-138.

Jolivet L, Daniel J M, Truffert C and Goffé B 1994 Exhumation of deep crustal metamorphic rocks and crustal extension in arc and back-arc regions; Lithos 33 3-30.

Jolivet L, Goffé B, Monie P, Truffert-Luxey C, Patriat M and Bonneau M 1996 Miocene detachment on Crete and exhumation $\mathrm{P}-\mathrm{T}-\mathrm{t}$ paths of high-pressure metamorphic rocks; Tectonics $\mathbf{1 5}$ 1129-1153.

Jolivet L, Faccenna C, Goffé B, Burov E and Agard P 2003 Subduction tectonics and exhumation of high-pressure metamorphic rocks in the Mediterranean orogens; Am. J. Sci. 303 353-409.

Jolivet L, Faccenna C, Huet B, Labrousse L, LePourhiet L, Lacombe O, Lecomte E, Burov E, Denèle Y, Brun J-P, Philippon M, Paul A, Salaün G, Karabulut H, Piromallo C, Monié P, Gueydan F, Okay A I, Oberhänsli R, Pourteau A, Augier R, Gadenne L and Driussi O 2013 Aegean tectonics: Strain localisation, slab tearing and trench retreat; Tectonophys. 597-598 1-33.

Kamberis E, Bathrellos G D, Kokinou E and Skilodimou H D 2012 Correlation between the structural pattern and the development of the hydrographic network in a portion of the Western Thessaly Basin (Greece); Cent. Eur. J. Geosci. 4(3) 416-424.

Keller E 1986 Investigation of active tectonics: Use of surficial earth processes; In: Active Tectonics Studies in Geophysics (ed.) Wallace R E (Nat. Acad. Press, Washington DC), pp. 136-147.

Keller E A and Pinter N 1996 Active Tectonics: Earthquakes, Uplift and Landscape (Prentice Hall, Upper Saddle River, New Jersey).

Kilias A, Fassoulas C and Mountrakis D 1994 Tertiary extension of continental crust and uplift of Psiloritis metamorphic core complex in the central part of the Hellenic Arc (Crete, Greece); Geol. Rundsch. 83 417-430.

Kokinou E, Alves T and Kamberis E 2012 Structural decoupling on a convergent forearc setting (Southern Crete, Eastern Mediterranean); Bull. Geol. Soc. Am. 124(7-8) 1352-1364.

Kokinou E and Kamberis E 2009 The structure of the Kythira-Antikythira strait, offshore SW Greece (35.7 $36.6 \mathrm{~N})$, In: Geodynamics of Collision and Collapse at the Africa-Arabia-Eurasia subduction zone; (eds) van Hinsbergen D J J, Edwards M A and Govers R, Geol. Soc. Spec. Publ. $311343-360$.
Kokinou E, Moisidi M, Tsanaki I, Tsakalaki E, Tsiskaki E, Sarris A and Vallianatos F 2008 A seismotectonic study for the Heraklion basin in Crete (southern Hellenic Arc, Greece); Int. J. Geol. 1(2) 9-16.

Kokinou E, Kamberis E, Sarris A and Tzanaki I 2010 Geological and magnetic susceptibility mapping of mount Giouchta (central Crete); Bull. Geol. Soc. Greece, Proc. of the 12 $2^{\text {th }}$ Int. Cong. XLIII, $1289-298$.

Kokkalas S and Doutsos T 2004 Kinematics and strain partitioning in the southeast Hellenides (Greece); Geol. J. 39 $121-140$.

Lyon-Caen H, Armijo R, Drakopoulos J, Baskoutas J, Delibassis N, Gaulon R, Kouskouna V, Latoussakis J, Makropoulos K, Papadimitrou P, Papanastassiou D and Pedotti G 1988 The 1986 Kalamata (south Peloponnesus) earthquake: Detailed study of a normal fault, evidences for east-west extension in the Hellenic arc; J. Geophys. Res. 93 14,967-15,000.

Mercier J 1976 La néotectonique, ses méthodes et ses buts. Un exemple: l'arc égéen (Méditerranée orientale); Rev. Geogr. Phys. Geol. 18(2) 323-346.

Mercier J L 1981 Extensional-compressional tectonics associated with the Aegean Arc: Comparison with the Andean Cordillera of south Peru-North Bolivia; Phil. Trans. Roy. Soc. London A 300 337-355.

Mercier J L, Sorel D, Vergely P and Simeakis K 1989 Extensional tectonic regimes in the Aegean basins during the Cenozoic; Basin. Res. 2 49-71.

Meulenkamp J E 1979 Field guide to the Neogene of Crete; Dept. Geol. Pal. Univ. Athens Ser. A 32 1-31.

Meulenkamp J E, van Der Zwaan G J and van Wamel W A 1994 On late Miocene to recent vertical motions in the Cretan segment of the Hellenic arc; Tectonophys. 234 53-72.

Meulenkamp J E, Wortel M J R, van Wamel W A, Spakman W and Hoogerduyn Straating N E 1988 On the Hellenic subduction zone and the geodynamic evolution of Crete since the late Middle Miocene; Tectonophys. 146 203-215.

Migiros G, Bathrellos G D, Skilodimou H D and Karamousalis T 2011 Pinios (Peneus) River (Central Greece): Hydrological-geomorphological elements and changes during the Quaternary; Cent. Eur. J. Geosci. 3(2) $215-228$.

Mitra S 2002 Structural models of faulted detachment folds; AAPG. Bull. 86(9) 1673-1694.

Panagopoulos G P, Bathrellos G D, Skilodimou H D, Martsouka F A and Makropoulos K 2012 Mapping urban water demands using multi-criteria analysis and GIS; Water. Resour. Manag. 26(5) 1347-1363.

Papadopoulou-Vrynioti K, Bathrellos G D, Skilodimou H D, Kaviris G and Makropoulos K 2013 Karst collapse susceptibility mapping considering peak ground acceleration in a rapidly growing urban area; Eng. Geol. 158 77-88.

Pirazzoli P, Laborel J and Stiros S 1996 Coastal indicators of rapid uplift and sudsidence examples from Crete and other Mediterranean sites; Z. Geomorphol. Suppl. 102 21-35.

Pirazzoli P, Thommeret J, Thommeret Y, Laborel J and Montagionni L 1982 Crustal block movements from Holocene shorelines: Crete and Antikythira (Greece); Tectonophys. 68 27-43.

Ring U and Reischmann T 2002 The weak and superfast Cretan detachment: Exhumation at subduction rates in extruding wedges; J. Geol. Soc. London 159 225-228.

Ring U, Brachert $\mathrm{T}$ and Fassoulas C 2001 Middle Miocene graben development in Crete and its possible relation to large-scale detachment faults in the southern Aegean; Terra Nova 13 297-304, doi: 10.1046/j. 1365-3121.2001.00359.x.

Roberts G G, White N J and Shaw B 2013 An uplift history of Crete; Geomorphology 198 177-188. 
Rockwell T, Keller E and Johnson D 1984 Tectonic geomorphology of alluvial fans and mountain fronts near Ventura, California; In: Tectonic Geomorphology (eds) Morisawa M and Hack T J (Publ. in Geomorphology, State University of New York, Binghamton), pp. 183207.

Rozos D, Bathrellos G D and Skilodimou H D 2011 Comparison of the implementation of Rock Engineering System (RES) and Analytic Hierarchy Process (AHP) methods, based on landslide susceptibility maps, compiled in GIS environment. A case study from the Eastern Achaia County of Peloponnesus, Greece; Environ. Earth. Sci. 63(1) 49-63.

Rozos D, Skilodimou H D, Loupasakis C and Bathrellos G D 2013 Application of the revised universal soil loss equation model on landslide prevention. An example from N. Euboea (Evia) Island, Greece; Environ. Earth. Sci. 70(7) 3255-3266.

Silva P G, Goy J L, Zazo C and Bardají T 2003 Faultgenerated mountain fronts in south-east Spain: Geomorphologic assessment of tectonic and seismic activity; Geomorphology 50 203-225.

Skilodimou H, Livaditis G, Bathrellos G and VerikiouPapaspiridakou E 2003 Investigating the flooding events of the urban regions of Glyfada and Voula, Attica, Greece: A contribution to urban geomorphology; Geogr. Ann. A 85(2) 197-204.

Stiros S C 1996 Late Holocene relative sea level changes in SW Crete: Evidence of an unusual earthquake cycle; Ann. Di. Geophys. 49(3) 677-687.

ten Veen J H and Postma G 1999 Neogene tectonics and basin fill patterns in the Hellenic outer-arc (Crete, Greece); Basin. Res. 11 223-241.

Theocharis D and Fountoulis I 2002 Morphometric indices and tectonically active structures: The case of Salamis island; Proc. of the 6th Panhellenic Geogr. Congress Geogr. Soc. Greece I 97-106 (in Greek with English abstract).

Tortorici L, Caputo R and Monaco C 2010 Late Neogene to Quaternary contractional structures in Crete (Greece); Tectonophys. 483 203-213.

Tsodoulos I M, Koukouvelas I K and Pavlides S 2008 Tectonic geomorphology of the easternmost extension of the Gulf of Corinth (Beotia, central Greece); Tectonophys. $453211-232$.

Turowski J M, Lague D, Crave A and Hovius N 2006 Experimental channel response to tectonic uplift; J. Geophys. Res. 111 F03008, doi: 10.1029/2005JF000306.

Turowski J M, Lague D and Hovius N 2009 Response of bedrock channel width to tectonic forcing: Insights from a numerical model, theoretical considerations, and comparison with field data; J. Geophys. Res. 114 F03016, doi: 10.1029/2008JF001133.

van Hinsbergen D J J and Meulenkamp J E 2006 Neogene supra-detachment basin development on Crete (Greece) during exhumation of the South Aegean core complex; Basin. Res. 18 103-124.

Verrios S, Zygouri V and Kokkalas S 2004 Morphotectonic analysis in the Eliki fault zone (Gulf of Corinth, Greece); Bull. Geol. Soc. Greece 36 1706-1715.

Wells S G, Bullard T F, Menges C M, Drake P G, Karas P A, Kelson K I, Ritter J B and Wesling J R 1988 Regional variations in tectonic geomorphology along a segmented convergent plate boundary, Pacific coast of Costa Rica; Geomorphology 1(3) 239-265.

Zachariasse W J, van Hinsbergen D J J and Fortuin A R 2011 Formation and fragmentation of a late Miocene supra-detachment basin in central Crete: Implications for exhumation mechanisms of high-pressure rocks in the Aegean forearc; Basin Res. 23 678-701. 